\title{
Kent Kimliğinin Kent Meydanlarına Yansıması: Alanya İskele-Rıhtım Bölgesi Örneği
}

\author{
Ali TÜRK ${ }^{1}$, Hatice Selcen SEYDiOĞULLARI ${ }^{1 *}$ \\ ${ }^{1}$ Süleyman Demirel Üniversitesi, Mimarlık Fakültesi, Isparta \\ Geliş Tarihi (Received): 28.02.2018, Kabul Tarihi (Accepted): 12.07.2018 \\ $\square$ Sorumlu Yazar (Corresponding author ${ }^{\star}$ ): seydiogullari_sel@hotmail.com \\ (C) +902462111639 成 +902462118231
}

\section{öz}

İlkel toplumların oluşturduğu yerleşimlerden günümüz kentlerine kadar toplumların kültürel, ekonomik ve fiziksel yönden birçok aktivitede bulunduğu kent meydanları, kentlerin kimliğini yansıtan önemli kentsel mekânlardır. Plansız büyüyen kentler, tarihsel süreçte sahip oldukları ve onları birbirinden farklı kılan kimlik bileşenlerini zamanla kaybetmektedir. Tarihin her döneminde ve her toplumda farklı şekillerde ortaya çıkan kentsel açık alanların son ve en güzel örneklerinden birisi kent meydanlarıdır. Çalışmanın çıkış noktası kent meydanı bulunmayan kentlerde, kent kimliğinin kent meydanları üzerinde etkisinin neler olabileceği düşüncesi oluşturmuştur. Alanya İskele-Rıhtım bölgesi özelinde yapılan mekânsal analizler ve anket neticesinde; bölgenin mevcut durumda kentin odak merkezlerinden olup, sosyal ve kültürel aktiviteleri karşılamada yetersiz kaldığı, içerisinde iki adet küçük meydanlar bulunduğu belirlenmiştir. Bu meydanların kent büyümesi ile ilişkilendirildiğinde yetersiz kaldığı, ulaşım sistemi ve görsel değerleri incelenmiştir. Anket çalışmaları neticesinde ise, kullanıcıların olmasını istedikleri kültürel değer ve aktivitelerin, ekonomik faaliyetlerin, çalışma alanı ile ilgili diğer istek ve beklentilerinin neler olabileceği hakkında veriler elde edilmiştir. Bu çalışmanın sonucunda; İskele-Rıhtım Bölgesi ve çevresindeki kentsel odaklar ile bütünleşme sağlayamadığı, toplumsal intiyaçlara kentin kimliği ile örtüşen özelliklere meydan olarak cevap veremediği, sosyal ve kültürel özellikleri ile çevresel ve toplumsal kimlik bileşenleri doğrultusunda birer odak noktası olduğu sonucuna ulaşılmıştır.

Anahtar Kelimeler: Kent, kent kimliği, kentsel mekân, meydan, kent meydanı

\section{Reflection of Urban Identity on City Square: Alanya Iskele-Rıhtım Region Sample}

\begin{abstract}
Urban squares, from the settlements formed by primitive societies to contemporary cities, where many societies have cultural, economic and physical activities, are important urban spaces reflecting the identity of the cities. Cities that have grown without a plan lose their identity components in time, which they have in the historical process and are different from each other. Urban squares are one of the last and best examples of the urban open spaces that emerged in different forms in every period of history and in every society. The starting point of the work was the idea of what might be the effect of urban identity on urban squares in cities where there is no city square. As a result of spatial analyzes and questionnaires made specifically for the Alanya Iskele-Rıhtım region; It is determined that the city has two small squares in which the city is currently the focal point of the city and inadequate to meet social and cultural activities. The transportation system and visual values, which are inadequate when these
\end{abstract}


squares are associated with urban growth, have been examined. As a result of the questionnaire surveys, it was learned that what cultural values and activities users want to have, economic activities, other areas of work and expectation about their field of work could be. As a result of this study; the city has not been able to respond to social needs that are not integrated with the urban focal points of the Pier-Quay Zone and its surroundings, the characteristics that overlap with the identity of the city, the social and cultural characteristics and the focal points in terms of environmental and social identity components.

Keywords: City, urban identity, urban space, square, urban square

\section{Giriş}

Toplumların yaşam biçimlerini etkileyen, coğrafi, kültürel, sosyolojik, siyasal ve benzeri koşullar mevcuttur. Bu koşulların mekâna yansıyıp toplum yaşamını etkileyen boyutlarının nasıl olduğu ve neye göre şekillendiği hep merak edilen bir sorudur. İnsan, toplumsal bir varlıktır. Varoluşundan itibaren küçük topluluklar halinde yaşamıştır. Küçük topluluklar zamanla büyük topluluklara dönüşerek toplum içinde yaşamanın gerektirdiği kurallar ve davranışlar oluşmaya başlamıştır. İnsanoğlu yerleşik düzene geçince kentlerde zaman içerisinde kurulmuştur.

Kentlerin oluşumu; sosyal, kültürel, ekonomik ve teknolojik gelişmeler gibi farklı niteliklerle biçimlenmesine neden olmuştur. Tarihsel süreç içerisinde her toplum, yaşadığı dönemdeki yaşam biçimlerini ve düşüncelerini kentlere yansıtmış, böylece kentlerin özgünlüğünü yakalayabilmesinde etkili olan kent kimliği kavramını ortaya çıkmıştır. Kent kimliği, kenti diğer kentlerden ayırt etmeye, bir anlamda başkalaştırmaya yardımcı olan özellikler ve kente özgü olduğu tartışma götürmeyen öğeler olarak tanımlanmaktadır.

Correa (1983), kimliğin bir süreç olduğuna değinerek, kimliğin üretilemeyeceğine ve amaçlı yapılan bir şey olamayacağına değinmektedir. Kimlik, bir varoluş tarzının ürünüdür. Bir kimliğin oluşumu, belli koşulların sürekliliği neticesinde gerçekleşmektedir (Bayramoğlu, 2010).

Bir kentin kimliği; doğal ve yapay çevreden kaynaklanan kimlik elemanları, bu elemanların mekânsal öğeleri, tarihi, kültürel değerleri ve düzeyi, mimarisi, sosyal yapısı, coğrafyası, içinde yaşayan uygarlıkları, yerel gelenekleri, yaşam biçimi, şu anda yaşayan insanları, ilk yerleşimden bugüne geçirdiği evreleri, topografyası, bitki örtüsü, iklimi, jeopolitik konumu, Doğu veya Batı kenti oluşu, deniz ve karayolu bağlantısı, başka kültürlere olan açıklığı veya kapalıığı, ekonomik yapısı, barındırdığı canlı türleri, geçirdiği işgaller ve savaşlar, depremler, bir devlete başkentlik yapıp yapmadığı vb. birçok etken ile değişebilmekte ve böylelikle kendine has özellikler kazanmaktadır (Topçu, 2011).
Kent kimliğini oluşturan kentsel mekânlar içerisinde en önemli ögelerinden biri kent meydanıdır. Kentsel mekânlar, toplumun istek ve gereksinimleri doğrultusunda şekillenir. Bu biçimi oluşturan, sokaklar, binalar, yeşil alanlar, meydanlar, yapılaşmış ve yapılaşmamış alanlar kentsel mekânı oluşturmaktadır. İnsanların bir arada bulunma isteği kentlerde açık ve kapalı mekânların oluşmasına neden olmuştur. Böylece ortak yaşamın gerçekleştiği, kentte önemli fonksiyonlara sahip, sosyal, ekonomik ve kültürel değerlerle geçmişle gelecek arasında bağ kuran kent meydanları oluşmuştur. Meydanlar, insanların sosyal aktivitelerini gerçekleştirdiği, birbiriyle etkileşim içinde bulunduğu, intiyaçlarını karşıladığı, sosyalleştiği, siyasal, sosyal ve ekonomik şartlara göre biçimlenen mekânlardır.

İnsanların kullandığı ilk kamusal mekânlardan biri olan kent meydanlar, tarihsel süreçte üstlendikleri farklı işlevlerle kentsel yaşamın önemli bir parçası olmuşlardır. Kent meydanları, kentsel dokuda odak noktalarını tanımlar ve toplanma işlevini içerirler. Bu nedenle, kent meydanları kentte sürekli yaşayan nüfusun ve kenti geçici bir süre için ziyaret eden kişilerin birbirleriyle ve paylaştıkları kent ile ilişki kurmasını sağlar. Tüm kent halkına eşit kullanım olanağı sunan bu alanlar, çeşitli etkinlikler için ortak bir platform oluşturur (Kalender ve Demiroğlu, 2011).

Schulz (1971)'a göre meydanlar, "kentsel yapının en belirgin ve en göze çarpan unsurudur". Meydan, "binalar tarafından çerçevelenmiş ve binalarını en iyi şekilde sergilenmesi için tasarlanmış alandır" (Moughtin, 2003).

Özdeş (1985), kent meydanlarını genellikle hükümet binaları, adliye, resmi binalar gibi şehrin anıtsal yapıları ile çevrelenmiş toplanma merkezi olarak tanımlar (Altınçekiç, 2000). Özkan vd. (1994)'ne göre kent meydanı, kentsel sirkülasyonu başlatma ve yönlendirme ile kent insanına toplanma mekânı olarak hizmet veren geniş açık alanlar olup, bu mekânlar her türlü yerleşim biriminin odak noktası ya da odak noktalarıdır. Kent meydanları, halkın ticari, dini, kültürel, politik ve ulusal amaçlarla bir araya geldiği açık yaşama mekânlarıdır (Kalender ve Demiroğlu, 2011). 
Marcus ve Francis (1990) kentsel plaza olarak ifade ettiği, tarihi özellik taşımayan kent meydanlarını, araçların dışında tutulmuş, yoğun olarak sert yüzeylere sahip, kamusal dış mekânlar olarak tanımlamıştırlar.

Zucker (1959)'e göre; Kent meydanları, tarih boyunca kentlerimizin kimliğini ve kişiliğini ortaya koyan önemli bir kentsel yaşam odağıdır (Altınçekiç vd., 2014). Kent meydanları, geçmişten günümüze kentlerimizin kimliğini ortaya koyan önemli bir kentsel yaşam merkezi iken, günümüzde taşıt meydanları veya otopark olarak kullanılarak kendine özgü değerlerini yitirdiği kentsel boşluklardır. Kent meydanları, insanlara istemli veya istemsiz gelişigüzel hareketlilik sağlayan, sürekli ve zorunlu bir hareket düzeninden çok, durma imkânı veren ve hareketle zorlamayan mekânlardır. Kent meydanları, tarih boyunca sosyal, kültürel, ekonomik ve idari fonksiyonları içlerinde bulundurarak, toplum kültürünü üç boyutlu kimliği olarak yansıtmıştır ve yansıtmaya devam edecektir.

Meydanlar ilk çağlardan günümüze insanların toplumsal iletişim intiyacını karşılayan en önemli kamusal mekân olarak karşımıza çıkmıştır. Çatalhöyük'te M.Ö.6000'de konut gruplarının bir avlu etrafında toplanmasıyla oluşan avlular, tarihteki 'ilk meydan' örnekleridir. Bu tipoloji içerinde kalan alanın önemli ölçüde kontrolünün sağlayarak savunma işlevini yerine getirmiştir. Tanımlanabilir ilk örneğine Yunan kentlerinde "agora" denilmiştir (Aykurt, 2010). Antik Yunan döneminde kentlerin içinde farklı toplumsal konuların tartışıldığı agoralar, daha sade ve işlevsel yaşam tarzını oluşturmuştur. Ortaçağda geometrik formlara sahip olmayan fakat birden fazla heykelin sergilendiği meydanlar, öncelikle yayalara hizmet veren, insanı ön plana çıkaran ve sanatsal yaşam tarzını ortaya koyan mekânlardır. Rönesans döneminde denge öğelerinin egemen olduğu meydanlar, şekilciliği prensip alan yaşam tarzı$\mathrm{nı}$, Barok dönemde hareketliliğin ortaya konulduğu meydanlara bırakmıştır. Süslü ve gösterişli yaşam tarzını, modern dönemde artan iş temposuyla birlikte artan araç trafiğine cevap veren, kent içinde sıkışıp kalmış durumda olan meydanlar ise daha mekanik bir yaşam tarzını ortaya koymaktadır.

Mesutoğlu (2001)'na göre, meydanlar işlevlerine ve biçimlerine göre sınıflandırılabilir, ancak işlevlerine göre biçimlerini ve biçimlerine göre işlevlerini belirtecek bir sınıflandırma mümkün değildir. Meydanlar ile ilgili önemli tartışmaların başında biçim-işlev etkileşimidir. Acaba işlev mi biçimi yoksa biçim mi işlevi belirlemektedir? Antik yunan döneminden günümüz meydanlarına kadar incelemiş olursak, meydanların işlevlerinin biçimsel niteliklerini etkilediği görülmektedir.
Meydanların biçimsel niteliklerini tanımlarken belirli ve kesin biçim, kapalılık hissi, estetik, ölçek ve sınırlayıcılardır. Meydanlar sadece boşluk yaratan mekânlar değil, insan davranışlarını da düzenleyen, bütüncül bir mekândır.

Krier, meydanın işlevlerini şu şekilde özetlemiştir: "Özellikle ticarî aktiviteler, örneğin pazar olarak, fakat hepsinin üzerinde kültürel doğası olan aktiviteler. Kamu toplanma alanları (community halls), idarî merkezler, gençlik merkezleri, kütüphaneler, tiyatrolar, barlar, kafeler gibi müesseseler meydan etrafında yer almalıdır. Ve mümkün ise kentsel hayat gerektiriyor ise bunlar yirmi dört saat bu intiyacı karşılar halde olmalıdır. Merkez meydanlar olduğu durumlarda bunlar gereklidir ama bunların yanında yerleşim alanları da inmal edilmemelidir (Taşçı, 2012).

Kent kimliği kavramsal olarak açıkladığımızda; kentsel mekân, meydan ve kent meydanı ile doğrudan ve dolaylı olarak ilişki içinde olduğunu görmekteyiz. Bir kentte yaşayanların kimliği de kentin kimliğini etkileyen faktörlerden biridir. Kent kimliği, geçmişin korunması ve bugün yaşanılan kültürün yaşatılmasına bağlıdır. Bir toplumun kültürel birikimi ve birbiriyle olan etkileşimi mekânın oluşmasını sağlamış ve bu mekân, kentin bütünleşme aracı olarak kabul edilmiştir. Bir kentin kimliğinin olması, onu diğer kentlerden ayırıp, tanınır hale gelmesini sağlamıştır. Bir kentin kimliğini; sınırlayıcıları, o kentin fiziki özellikleri, düğüm noktaları (meydanları), odak noktaları ve yolları belirlemiştir. Özellikle tarihsel süreç içerisinde yaşanan siyasi ve kültürel olaylar, kentlerin yeniden şekillenmesine, kent kimliğinin değişmesine neden olmuş ve bunların mekânlara yansıması ile somut hale gelmiştir.

\section{ALANYA'NIN TARIHÇESI}

Alanya kentinin tarih öncesi devirlerine ait tanınan belgeler günümüzde sınırlı olmakla birlikte bölge tarihinin, 1957 yılında Kadıini Mağarası'nda yapılan araştırmalar sonucunda M.Ö. 20.000'li (üst paleolitik) yıllara uzanmaktadır ve ilk ne zaman, kimler tarafından kurulduğu henüz bilinmemektedir. Alanya kenti; antik çağlarda Pamfilya ve Kilikya arasında, kuzeyinde Toroslar ve güneyinde Akdeniz'in olduğu, korsanlara ev sahipliği yapan yarımada şeklinde Korakesion (Coracesium) adı verilen bir yerleşim yeridir. Bizans döneminde Hristiyanlık dinini kabul eden kent, gemiciler için önem teşkil etmiş ve kentin bulunduğu yarımadaya Kalonoros (Güzel Dağ) ismini vermişlerdir. 13. yüzyılda Anadolu Selçuklu Sultanı I. Alaaddin Keykubat, Hristiyan derebeyi Kyr Vart'ı yenilgiye uğratarak, 1221 yılında kaleyi ele geçirmesiyle kent, Alaiye ismini almıştır. I. Alaaddin Keykubat, Alaiye kentini kışlık başkent olarak kullanmaya başlamış, kente getirdiği zanaatkârlar ve bilgin- 
lerle birlikte askeri, dini ve sivil mimari eserlerle donatarak, Türk İslam beldesi haline getirmiştir. 1923'te Cumhuriyetin ilan edilmesinden sonra, 1935 yılında Alaiye kentini ziyarete gelen Mustafa Kemal Atatürk kente "Alanya" ismini vermiştir.

Alanya kenti, tarihin çeşitli dönemlerinden itibaren önemli yerleşim yerlerinden biri olmuş, kentsel yerleşim birimi olarak niteliği korumuştur. Alanya kentinin fiziki ve coğrafi koşulları kentsel ve mekânsal gelişimi sağlamış, kentin büyümesinde ve gelişmesinde önemli rol oynamıştır. İlk yerleşim biriminin, günümüzdeki Hisariçi mahallesi sınırları içerisinde kalındığı bilinmektedir. Osmanlı döneninin en önemli mekânsal gelişmelerinden biri yerleşimin kıyı ovasına doğru inmeye başlaması ve Akdeniz'in en büyük tersanesine sahip olmasıdır. 19. Yüzyıldan itibaren, sur içinden sahile doğru yayılma başlamış ve bu gelişme sahil bölümünde yeni bir şehrin (mekânsal gelişme) meydana gelmesine sebep olmuştur. Cumhuriyet dönemine geçiş ile birlikte liman kenti özelliğine sahip Alanya kenti, ikinci derece geçim kaynağı olan tarımsal faaliyetlere yönelmiş ve bu ekonomik faaliyetlerle birlikte kentsel gelişme önem kazanmıştır.

1950'li yıllarından başından itibaren Türkiye genelinde hız kazanan karayolu yapım çalışmalarına bağlı olarak, etkisi Alanya kentinde de görülmüş ve kent ulaşımı hızla dışarıya açılmıştır. Batıda Antalya ve doğuda Mersin illerini birbirine bağlayan ulaşım ağına sahip olmuştur. 1957 yılında günümüzde kent merkezinin en işlek ve önemli caddelerinden olan Ahmet Asım Tokuş Caddesinin yapımına başlanmış, Alanya kent kimliğini yansıtan ve iskele caddesinde konumlanan birçok ev bu dönemde denizyolu ile getirilen iş araçlarının taşınması için yıkılmıştır. Bu dönemde Ahmet Asım Tokuş Caddesi kent merkezinin en önemli yolu olup, turistik yol olarak adlandırılmaktadır. Böylelikle kentin mekânsal gelişimi, kuzey ve doğu yönünde eğilim göstermiştir. Bu dönemle birlikte iskele ve rıhtımın olduğu bölge mekânsal anlamda önem kazanmıştır.

Alanya kenti, 1960 'lı yıllar ile birlikte mekânsal gelişim ve kentsel fonksiyonların hızla arttığı döneme girmiştir. 1960'li yıllarda kıyı ovalarında balık hali, ticari merkezler, narenciye depoları, sosyo-kültürel anlamda kahvehaneler bulunmaktadır. Ulaşım ağının güçlenmesi ve tarımsal üretimin artması ile kentte ihracatın artmasını sağlamıştır. Bu dönemde mekânsal doku kıyı ovası üzerinde oluşan gevşek dokulu yapıların arası dolmuş ve sık dokulu bir yapılaşma halini almıştır.

1970'lerden itibaren kentte ev pansiyonculuğu gelişmeye başlamıştır. Kentin kale arkası mevkiinde bulunan ve astım hastalığına iyi gelen 1954 yılında bulunan Damlataş mağarası, bu dönemde kentte sağlık turizminin başlamasını sağlamış ve böylece kent turizm kenti olma yolunda ilk adımını atmıştır. 1974 yılına gelindiğinde mevcut rıhtım uzatılmış, iki yıl sonra da rıhtımın hemen yanında bir balıkçı barınağı inşa edilmiştir.

1980 yılından itibaren Alanya kentinde turizm yatırımları ve teşvikleri başlamış, böylelikle kent turizmin etkisiyle hızla gelişmiştir. 1980'li yılların başında kıyı ovası seyrek yerleşimin yerini çok katlı yapılar ve aralarındaki tarım alanlarından oluşmaktadır. 1982 yılında kabul edilen Turizmi Teşvik Kanunu'nun ile birlikte Alanya kentinin doğu ve batısı turizm merkezi olarak ilan edilmiş ve turistik yatırımlara hız kazandırmış ve kitle turizmi gelişmiştir. Kentin turizme etkisiyle kıyı ovası üzerinde geniş tarım alanları arasındaki çok katlı yapılar oluşmuştur.

Kentsel donatı anlamında; günümüzde kent meydanı olarak kullanılan Atatürk anıtının bulunduğu meydan 1980-1982 yılları arasında yapılmıştır. Bu tarihe kadar kentin Kuyularönü meydanından sonra 2. büyük meydanı olup, anıtım yerinde Bektaş çeşmesi adı verilen bir çeşme ve çınar ağacı bulunmaktadır. Atatürk anıtının yapılması ile birlikte kentin ana meydanı konumunu almıştır. 1984-1986 yılları arasında kentin kıyı kesimleri doldurulmaya başlamıştır. Eski İskele Caddesi'nin altındaki rıhtım ile kıyı arası doldurularak, 1984-86 yılları arasında yeni bir gezi alanı, kruvaziyer gemilerinin yanaşabileceği bir rıhtım ile tur tekneleri için bir barınak yapılmıştır. 1990'lardan günümüze doğru geldiğimizde Alanya kentinin kıyı bandında ve ovasında birçok turistik otel ve işletmeler açılmış, kenttin kuzeye doğru yerleşim alanı yayılmıştır. Günümüzde kentin durumuna bakıldığında yerleşim kentin kuzeyine doğru ilerlemiş ve yayılmış durumda olup, kentte tarım ve turizm sektörü ekonomik faaliyetlerin başında gelmektedir. 1980 'lerin sonunda turizmin etkisiyle plansız kentleşme, kenti beton yığını haline getirmiştir.

1980'li yıllarda kıyı ovası ve çevresinde çok katıı binalar ve aralarındaki ufak tarım alanları şeklinde yerleşim alanı oluşmuştur. İller Bankası tarafından yapılan "Alanya kasabası" ait 1/1000 ölçekli ilk hâlihazır harita 20.11.1974 yılında onaylanmıştır. Kıyı kenar ekibi tarafından yapılan inceleme sonucunda ise 06.02.1976 Kıyı Kenar Çizgisi onaylanmış, Alanya ilçesinin ilk imar planı 10.10.1984 tarih ve 8. Sayılı B.M.K ile onaylanmıştır. Alanya kenti sınırlarını kapsayan 1/25.000 ölçekli Doğu Antalya Çevre düzeni planı (Serik-Manavgat-Alanya Doğu Çevre Düzeni Revizyon Planı) Bayındırlık ve İskân Bakanlığı tarafından 29.05.1990 tarih ve 10 sayılı kararı ile onanmıştır. Tarım faaliyetleri 1987 'den itibaren 2. plana atılmış ve turizm sektöründe patlama yaşanmıştır (Şekil 1). Böylece birçok otel ve ikinci konutlar plajların üzerine kondurularak kumsallar yok edilmiştir. Şehir, bölgenin fiziki ve beşeri coğrafya özellikleri göz önüne alınmadan planlandığı için sonucunda da 
şehir bir beton yığını halini almıştır. Alanya kent merkezinin batı kıyıları turizm tesis alanı olarak öngörülmüştür.

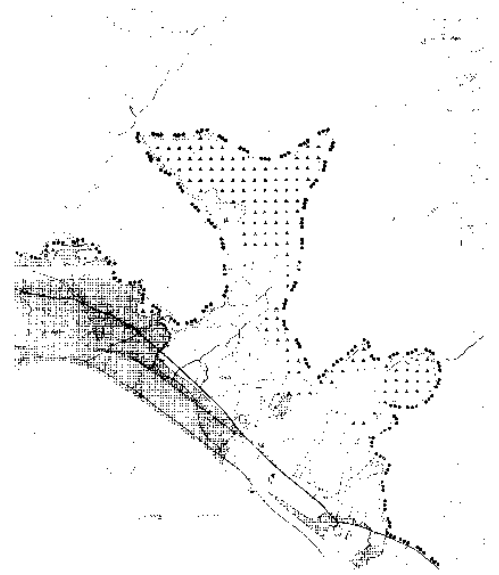

Şekil 1. 1990 yılı Doğu Antalya Çevre Düzeni Planı (Alanya Belediyesi, 2018)

Günümüzde halen yürürlükte olan Alanya imar planı 1996 yılında onaylanmıştır. Plan araştırma alanı olan iskele-rıhtım bölgesinin doğusunda ve batısında değişikliklerin yapılmasıyla onanmıştır. Araştırma alanı ile ilgili herhangi plan kararı değişmemiştir. Fakat araştırma alanı sınırlarını kapsayan Alanya Kalesi kıyı bandına etkileme geçiş alanı kentsel tasarım projesi 16.10.2001 yılında onaylanmıştır (Şekil 2). Bu kıyı bandı kentsel tasarım projesi sınırları, araştırma alanı sınırları ile aynı olup, bölge ile ilgili kullanım kararları verilmiştir. Projeye göre beş özel planlama alanı (ÖPA) belirlenmiş ve ÖPA1 olarak belirlenen bölgede iskele meydanı ve gümrük tesisi alanı yapılması öngörülmüştür. Bu bölge Kızılkule ve iskeleyi kapsayan bölgedir. ÖPA2 bölgesi; terasılı kafeteryalar, ÖPA3 bölgesi; açık hava toplanma ve gösteri alanı, ÖPA4 bölgesi; turistik ticaret tesis alanı ve gezinti iskelesi, ÖPA5 bölgesi de mevcut turistik ticaret alanı (lokantalar) olarak öngörülmüştür.

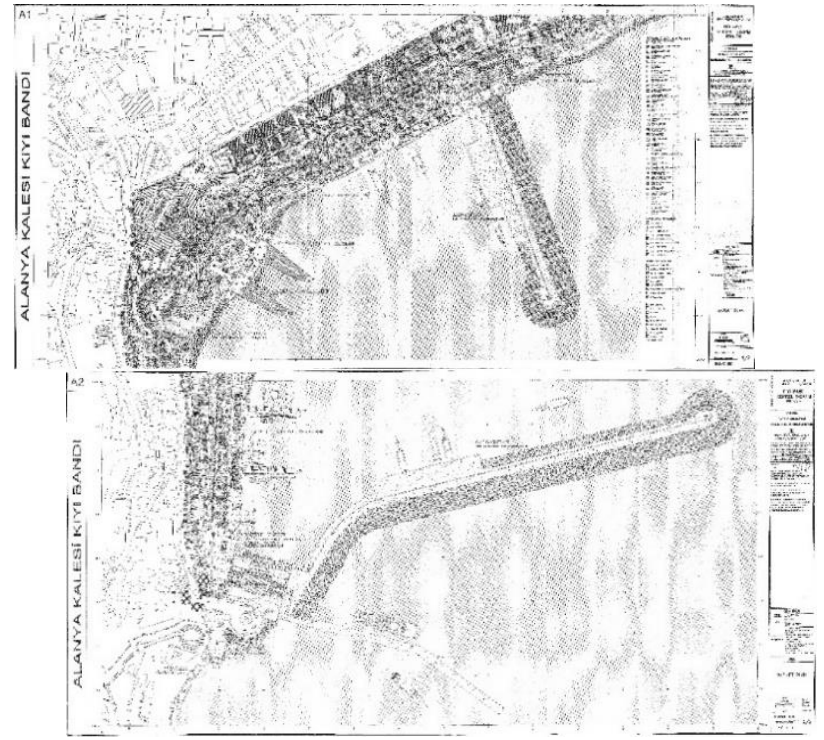

Şekil 2. 2001 yılı Kıyı bandı kentsel tasarım projesi (Alanya Belediyesi, 2018)

Antalya-Burdur-Isparta Planlama Bölgesi 1/100.000 Ölçekli Çevre Düzeni Planı, 644 sayılı Kanun Hükmünde Kararnamenin 7.maddesi uyarınca 15.04.2014 tarihinde onaylanmıştır. Plana yapılan itirazlar sonucunda; 23.03.2015 ve 27.08.2015 tarihlerinde değişiklikler yapılarak planlar yeniden onanmıştır. Alanya kenti, Alanya-Gazipaşa odaklı kentsel gelişme bölgesi olarak, denize kıyısının olmasının yanı sıra, bölgede sınırları içinde bulunan turizm merkezleri ile turizm tesisleri bölgede turizm sektörünün gelişmesini sağlamıştır. Onaylanan çevre düzeni planından önce onaylanan 1/1.000 ölçekli uygulama imar planı ve 1/5.000 ölçekli nazım imar planı bulunduğu halde, planda $2 \mathrm{~B}$ ya da tarım alanı olarak gösterilen bölgelerin bulunması nedeniyle tutarsızlıklar oluşmuştur. Bu tutarsızlıkların giderilmesi amacıyla Antalya Büyükşehir Belediyesi'nin yetkisiyle 1/100.000 ölçekli Çevre Düzeni Planı değişikliği yapılmıştır. Plan, 22.01.2018 tarihi itibariyle askıya çıkmıştır. 


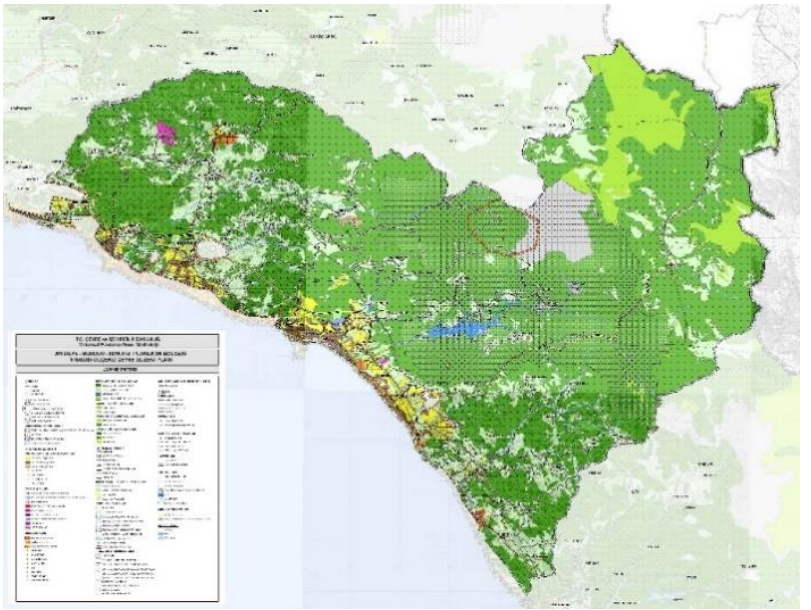

Şekil 3. 1/100.000 Ölçekli Çevre Düzeni Plan Değişikliği-Alanya (Antalya Büyükşehir Belediyesi, 2018)

Planda yapılması öngörülen Antalya-Konya-AksarayNevşehir-Kayseri hızlı tren güzergâhı ve Alanya çevreyolu projesi planda gösterilmiştir. Ayrıca kentte 2011 ve 2015 yıllarında resmi gazetede yayınlanmasıyla vakıf ve devlet üniversitesinin kurulması ile birlikte kentin doğu yönünde gelişimi hız kazanmıştır (Kestel, Çıplaklı ve Cikcilli Mahalleleri). Ayrıca, Oba Mahallesinde 2017 yılında faaliyete geçen Alaaddin Keykubat Eğitim ve Araştırma Hastanesi bölgenin mekânsal gelişimine yön veren önemli gelişmelerindendir. Alanya'nın doğusunda bulunan Gazipaşa ilçesinde yapılan Gazipaşa-Alanya havalimanı, ilk olarak 2006 yılında stol tipi havaalanı olarak faaliyetlere başlamış, 2010 yılında ise ilk kez ticari uçuşları gerçekleştirmiştir. Alanya kentinin doğusunda $45 \mathrm{~km}$ uzaklıkta bulunan havalimanı, kentin doğusunda bulunan ve 2013 yılındaki kabul edilen büyükşehir yasası ile birlikte mahalle statüsü alan beldelerin, havalimanı faaliyetleri ile birlikte mekânsal gelişimleri hızla artmıştır.

Hazırlanan 1/25.000 ölçekli Nazım İmar Planı doğrultusunda, araştırma alanı olan iskele-rıhtım bölgesi ve çevresinin bir bölümü plan onama dışı doğal, tarihi, kentsel ve arkeolojik sit alanı içerisinde, diğer bir bölümü ise park ve yeşil alan sınırları içerisinde kalmaktadır. Kentin doğu sahil şeridi ağırlıklı olarak ticaretturizm-konut alanları olarak öngörülürken, batı sahil şeridi turizm merkezi sınırları içerisinde kalmaktadır. Kentin gelişme alanları ağırlıklı olarak kentin doğusunda, bir kısmı tamamlanan ve yapımı devam eden çevreyolu ve çevresinde, bir kısmında hızlı tren hattının olduğu bölgelerde yoğunlaştığı görülmektedir. Kent bütününde 2010 yılından itibaren doğuya doğru mekânsal gelişim ile birlikte kentsel donatıların konumlanması açısından da etkili olmuştur. Araştırma alanı sınırları içerisinde bulunan belediye hizmet binası ile ilgili plan değişikliği de 2015 yılında kabul edilmiş ve Alanya kent merkezinin doğusundaki Oba Mahallesi sınırları içerisinde çalışmalara başlanmıştır. Çalışmalar halen devam etmektedir.

Tüm bu gelişmeler sonucunda; kentin mekânsal gelişiminin kuzey ve doğu yönünde olduğu görülmektedir.

\section{MATERYAL VE YÖNTEM}

Çalışmanın materyalini temelde araştırma alanı oluşturmaktadır. Araştırma alanını Alanya kent merkezinden seçilmiş İskele-Rıhtım bölgesi oluşturmaktadır. Araştırma alanı olarak seçilen ve Alanya kentinin merkezi olan İskele-Rıhtım bölgesi ve çevresi, Alanya kalesi ile birlikte en eski yerleşim bölgeleri ve kıyı ovasında konumlanmasından dolayı kentin odağı niteliğindedir. Çalışmanın ana materyalini, araştırma alanı olarak seçilen Antalya İli, Alanya İlçesi, İskele-Rıhtım bölgesine ait tarihsel gelişim verileri, fotoğraf, harita, projeler, planlar ve Alanya kentine ait kimlik öğeleri ile ilgili literatür verileri oluşturmaktadır. Ayrıca, Alanya İskeleRıhtım bölgesinde uygulanmış olan anket verileri de materyal olarak kullanılmıştır. Anket bulgularında SPSS programı ki-kare testi kullanılmıştır. Kullanıcılar, yalnızca araştırma alanı ve çevresi ile sınırlı kalmamış, kent bütünü ve düzenli ziyaretlerde bulunan 400 kullanıcının görüşüne yer verilmiştir.

$\mathrm{Bu}$ çalışmada; araştırma yöntemi olarak, tez konusu hakkında bilmemiz gereken kavramlar, tanımlar ve zamana dek hazırlanmış diğer bilimsel çalışmalar incelenmiştir. Bu bağlamda; Kavramsal açıklamalar oluşturulurken, bilmemiz gereken kent, kent kimliği, kentsel mekân, meydan ve kent meydanı kavramları araştırılmış ve bu kavramlar ile ilgili kaynaklar incelenmiştir. Çalışma konusunun materyali olarak tanımlanan araştırma alanı, genel özellikleri ve mekânsal gelişimleri ile araştırılmış; çevresel ve toplumsal kimlik bileşenleri, tarihsel süreçte oluşumları ve kent kimliği-kent meydanı ilişkisi ile ilgili veriler toplanmıştır. Tez çalışması ile ilgili anket yöntemi oluşturulmaya çalışılmıştır. Anket soruları hazırlanırken; mekânsal sorunlar hakkında bilgi verilmesi, kullanıcıların beklentilerinin neler olduğu bilgisini vermesi, kullanıcıların yaş, medeni ve eğitim durumu gibi kullanıcı profili oluşturulmaya çalışılmıştır. Verilen cevaplar derlenerek, öneriler ve fikirler üretilerek tez çalışması sonuçlandırılmıştır. Bu analizler ışığında sonuç kısmına ulaşılmış ve öneriler sunulmuştur. Her çalışma gibi, bu çalışmasının da ileride yapılması düşünülen ve hedeflenen Alanya kent meydanı projesine katkı sağlaması beklenmektedir.

Araştırma alanının kapsamı ve sınırları, Antalya ili, Alanya ilçesi, Çarşı ve Güllerpınarı Mahallesi, İskeleRıhtım Bölgesi ve çevresi olarak belirlenmiştir. Araştırma alanı ile ilgili hedef kitle Alanya kentinde yaşayan ve Alanya dışında yaşamasına rağmen belirli zamanlarda 
vakit geçiren veya turistik amaçlı ziyaret eden kullanıcılar olarak belirlenmiştir. Bu bağlamda; anket yöntemi ile kullanıcıların görüşleri alınmıştır. Örnek alan olarak, iskele-rıhtım bölgesi çevresi ile bir bütün şeklinde ele alınmıştır.

İskele-rıhtım bölgesi Alanya ilçesi kent merkezinde olup, batısı Alanya kalesi ve Damlataş, kuzeyi Şekerhane mahallesi, güneyi Akdeniz ve doğusu araştırma alanınında bir kısmının girdiği Güllerpınarı mahallesi ile sınırlıdır. Araştırma alanı olarak seçilen bölge ve çevresinde Hükümet konağı, belediye hizmet binası, çocuk parkı, park alanı, çay bahçesi, halk plajı, kızılkule, polis merkezi, sahil güvenlik komutanlığı, liman başkanlığı ve Alanya kentinin meydanı olarak adlandırılan Atatürk anıtının olduğu bölge bulunmaktadır. Araştırma alanı kıyı boyunca lineer bir şekilde uzanmakta olup, kentte yaşayan ya da uğrayanların yürüyüş yaptıkları, dinlendikleri, akşamları eğlence mekânlarını tercih ettikleri bölgedir.

Alanya kenti iskele-rıhtım bölgesi yani kıyı ovası ve çevresine yerleşmiş bir kent olarak coğrafi konumu nedeniyle tarih boyunca deniz ticareti yönünden aktif bir kent özelliğini korumuş liman şehri olarak görülmüştür. Kentte, birisi iskele-rıhtım bölgesi üzerinde konumlanan Alanya Yat limanı ve diğeri Alanya'nın batısında bulunan Alanya Marina olmak üzere iki adet liman bulunmaktadır. Limanların varlığı ticari ve turistik açıdan dış dünyaya açılan kapı konumundadır. Geçmişte limanın varlığı ile birlikte gelişen ticari aktiviteler, ulaşım olarak denizyolunun kullanılması ve yarımada şeklinde konumlanan kalesi ve çevresi kent içinde yaşayan yabanCı nüfusun artışı, kent bütününde fiziksel çevrede değişimlere neden olmuştur. Günümüzde kentin yerleşim yoğunluğu, merkez olarak nitelendirdiğimiz kıyı ovası ve çevresinde, sahil şeridi boyunca varlığını devam ettirmektedir.

Kentin kuzeyinin Toroslara dayanması karayolu ulaşımında gelişiminde etkili olmuş bu nedenle liman kenti olarak uzun yıllar varlığını sürdürmüştür. Akdeniz iklimi altında, ılıman kuşakta yer alan kent kuzeyinde Toroslar ve güneyinde Akdenizin yer alması kentin doğu-batı ekseninde gelişmesini sağlamıştır. Ayrıca yaz ve kış aylarının sıcak geçmesi kent bütünündeki binaların konumlanışı, balkon büyüklükleri, bahçe genişlikleri gibi yapı ölçeğinde fiziksel mekânı şekillendirmiştir. Kentte turizm, Dimçayı, Dim mağarası, Kadıini mağarası ve Damlataş mağarası ile birlikte yerli yabancı turistlerin kenti tercih etmelerine neden olmuştur.

1987 yılından itibaren kentte turizmin faaliyetlerinin artmasıyla birlikte her ne kadar tarım alanlarının tahribatına yol açsa bile kent; muz, narenciye, avakado, susam ve keçiboynuzu gibi üretimi önem teşkil etmek- tedir. Bu faktörler göz önünde bulundurulduğunda Alanya kenti bir liman kenti, kıyı kenti, tarım kenti ve turizm kenti kimliğine sahiptir.

Alanya kentinde geçmişten günümü kadar gelen ve tarihi yansıtan özellikle Selçuklu döneminin izlerini taşıyan Alanya Kalesi, Kızılkule, Tershane ve tophane gibi yapılar araştırma alanı çevresinde bulunan yapılar, yapı ölçeğinde kentin tarihi kimliğini yansıtan yapılar arasındadır.

Araştırma alanı içerisinde bulunan hükümet konağı ve ziraat bankası yine tarihi kimliğini ve Cumhuriyet dönemini yansıtan yapılar arasındadır.

Kentsel boşluklar olarak adlandırılan açık alanlar parklar, yayayolları, meydanlar toplumu bir araya getiren sosyal, ekonomik, kültürel olarak yerleşim ölçeğindeki kimlik kazandıran kent kimliği birleşenlerindendir. Bu bağlamda; geçmişten günümüze Kuyularönü camiinin olduğu bölge, Atatürk anıtının bulunduğu bölge açık alan olarak kent kimliğine önemli ölçüde katkı sağlamaktadır. Özellikle Kuyularönü Camii ve çevresi Osmanlı döneminden bu yana meydan görevi görmüş, geçmişten günümüze bütün siyasal, toplumsal ve ekonomik faaliyetlerin gerçekleştirildiği kentsel mekânlardan biridir. Günümüzde bu bölge meydan olma özelliğini yitirmiştir. Ayrıca, günümüzde Atatürk anıtının bulunduğu meydan, kent meydanı görevinde olup, birçok siyasi, toplumsal etkinliklerin ve kutlamaların yapıldığı alandır. Bu meydanın çevresinde hükümet konağı, belediye hizmet binası, iki park alanı ve bir çocuk parkı bulunmaktadır.

Kent merkezinde bütününde, önemli ana yollar ve caddeler büyük ölçüde günümüze ulaşmıştır. Bunların içinde Ahmet Asım Tokuş Caddesi, Atatürk Caddesi, İskele Caddesi, Gazipaşa Caddesi kent merkezinin omurgasını oluşturan kent kimliğini belirleyen yerleşim ölçeğindeki kentsel kimlik bileşenlerine sahiptir. Tarih boyunca Alanya kentinin ticari işlevini yüklenmiş önemli bölge olan Liman Bölgesi (İskele-rıhtım caddesi) kentin kimliğini etkileyen diğer önemli bölgelerdir. Araştırma alanını oluşturan iskele-rıhtım bölgesi içerisinde aynı zamanda eğlence mekânları ve restoranlar, kıyı boyunca oluşturulan yürüyüş yolu ve bu aks üzerinde oluşturulan etkinlik alanları kentin kimliğini yansıtan imaj öğeleridir. Ayrıca her dönem Bölge her mevsim tercih edilen, siyasi ve bayram kutlamalarında Atatürk anıtından başlayıp, Atatürk Caddesinde yürüyüşün devam etmesi ve iskele-rıhtım bölgesinde yürüyüşün devam etmesi ile belediye binasının arkası ya da Atatürk anıtının önüne gelinmesiyle son bulur.

Bölge sınırları içerisinde bulunan rıhtım şelale meydanı, bayram kutlamaları, turizm ve sanat festivali, Noel pa- 
zarı vb. etkinliklerin düzenlendiği alandır. Ancak, bu meydan kent meydanı özelliğinde değildir. Kent bütününe hizmet etmesine rağmen, yetersiz kalmaktadır. Büyük ölçekte yapılan konserler ve müzik etkinlikleri meydan özelliği olmamasına rağmen belediye hizmet binası ile deniz arasında kalan alanda yapılmaktadır. Araştırma alanı sınırları olarak belirlenen İskele-Rıhtım bölgesi, tüm bu faaliyetleri içerisinde barındırmaktadır. $\mathrm{Bu}$ bölge ve içinde barındırdığı fonksiyonların hepsi Alanya kentinin odak noktasıdır.

Alanya kenti, çevresinde kurulduğu kıyı ovası ve liman sayesinde sahip olduğu deniz ulaşımı, kentin diğer ülkelerle ilişkisini sağlamış, ticaret kolaylığı sağlamıştır. Bu sayede gelişen ticari faaliyetler ve turizmin patlaması ile birlikte nüfus gittikçe artmış, yeni yerleşim ve kullanım alanlarına intiyaç artmıştır. Cumhuriyet döneminden sonra özellikle 1985-2000 yılları arasında artan nüfus ve turizm faaliyetleriyle fiziksel, sosyo-kültürel ve sosyo-ekonomik yönde hızlı bir büyüme ve gelişme göstermiştir. Turizm amaçlı yapılan geziler kentin ticaretinde önemli rol oynamaktadır. Kent çok çeşitli kültürlerin bir araya geldiği yerleşim alanı olarak Alanya, kıyı kenti olma özelliği ile birlikte toplumsal aktivite ve intiyaçlarını karşılamak amacıyla iskele bölgesi önemli bir rol üstlenmiştir. Bu özellikler kentin kimliğini oluşturan diğer bileşenlerdir.

Araştırma alanı olan İskele-Rıhtım bölgesinde yapılan etkinliklerin başında 2000 yılından bu yana her yıl Mayıs ayında geleneksel Turizm ve Sanat Festivali yapılmaktadır. Festivalin amacı; Alanya kentinin bir kültür, bir medeniyet, bir tarih şehri olduğunu, kentin kimliğini oluşturan bileşenlerin farklı uluslara ve farklı kültürlere Alanya kentinin tanıtımını sağlamaktır. Her yıl Alanya kentinin kendine özgü değerlerinden bir tema ile yola çıkılan festivalde; yöresel yemek ve sanat stantları ile birlikte yöresel değerlerin sergilendiği ve müzik etkinliklerinin gerçekleştiği festival bu bölgede yapılmaktadır. Ayrıca, festivalde geçmişten günümüze Alanya kentinin sosyo-kültürel ve sosyo-ekonomik yapısını anlatan fotoğraf sergileri bulunmaktadır. Festival, Atatürk Anıtı önünden Yörük Göçü ve kortej ile başlayıp, araştırma alanı içerisinde bulunan rıhtım şelale meydanında konserler verilmektedir. Turizm ve Sanat festivali, Alanya kentinin toplumsal kimliğini yansıtan en önemli bileşenlerden biridir.

Alanya Uluslararası Noel pazarı, 2009 yılından bu yana Aralık ayında yapılan, yerleşik yabancıların ülkelerine ait yiyecek ve eşyaları sergilediği pazar olup, kentte yapılan büyük etkinliklerin arasında yer almaktadır. Alanya kentini, farklı kültür ve dinden olan insanların, barış ve huzur içerisinde yaşadığı dünyaya örnek bir şehir olması düşüncesiyle yapılması planlanmıştır. Pazarda yabancı derneklerle beraber STK'lar ve işlet- meler stant açmakta ve aynı zamanda yabancı müzik ve halk oyunları sergilenmektedir. Etkinliğin simgesi olarak, metalden yapılan 14 metrelik Noel ağacı kurulan Pazar içerisinde bulunmaktadır. Ayrıca, 2014 yılından bu yana yoğun katılım sebebiyle rıhtım şelale meydanında yapılan Noel pazarına ilginin artmasıyla birlikte, meydanın yetersiz kalmasından dolayı belediye hizmet binası arkasındaki alanda kurulmaktadır. Alanya kentinde yaşayan yerleşik yerli halkın bir kısmı Noel pazarının turizme etkisi olduğunu ve kentte yaşayan yabancıların kent ekonomisine katkısını olduğunu düşünürken, bir kısmı ise kentteki toplumsal kimliği zedelediğini ve kentte kültür erozyonu yarattığını düşünmektedir.

Bütün bu etkinlikler, çevresel ve toplumsal kimlik bileşenleri Alanya kent kimliğini oluşturmakta ve tüm bu bileşenlerin araştırma alanı ve çevresinde toplanması bölgeyi odak noktası, merkezi ve kimlik yansıtıcısı görevini yüklemiştir.

\section{BULGULAR}

Yapılan anket çalışmasına göre, kullanıcıların yaş aralığı/cinsiyet durumu incelendiğinde; kadın kullanıcıların $(\% 50,8)$, erkek kullanıcılardan $(\% 49,3)$ daha fazla olduğu saptanmıştır. 18-30 yaş aralığında kullanıcılar, toplam kullanıcıların \%29,8'i ile en fazla kullanıcı profilini oluştururken, 18 yaş ve altı kullanıcılar \%14 ile en az kullanıcı profilini oluşturduğu saptanmıştır.

Yapılan anket çalışmasına göre, kullanıcıların aylık gelir/eğitim durumu incelendiğinde kullanıcıların \%31'i 501-1000 TL aylık gelire sahip olup, en fazla kullanıcı profilini oluşturmaktadır. Kullanıcıların \%11.25'i ise 500 ve altı geliri ile en az kullanıcı profilini oluşturmaktadır. Eğitim durumunda ise kullanıcıların \%38.5'i ile en fazla lise mezunu iken, \%15 ile en az ilkokul mezunudur.

Yapılan anket çalışmasına göre, kullanıcıların ikamet yeri/yaşam süresi durumu incelendiğinde kullanıcıların en fazla \%44,5'i Alanya ilçe sınırları içerisinde merkez mahalleler dışında kalmaktadır. Kullanıcıların \%27,3'ü 6-10 yıl, \%21,8'i 16-20 yıl, \%21'i 20+ yıl, \%20,3'ü 11-15 yıl ve \%9,8'i 0-5 yıl süreyle yaşamaktadır. Alanya dışında yaşayan kullanıcılar daha önce Alanya ilçe sınırları içerisinde yaşamış olup, şuan itibariyle Alanya sınırları dışında yaşamaktadır.

Kullanıcılara Alanya kent kimliği dediğimizde akıllarına gelen ilk beş unsur ve Alanya kenti sizce ne kentidir diye sorular sorulmuştur. Kullanıcıların \%39,5'i (158) Alanya kentini turizm kenti, \%23,25'i liman kenti, \%21'i tarım kenti, \%11'i üniversite kenti ve $\% 5,25$ 'i sanayi kenti olarak tanımlamaktadır. Kullanıcıların 122'si Alanya'da kent kimliği denildiğinde akıllarına en çok Alanya kalesi ve Kızılkule geldiğini söylemiş ve kullanıcılar 
Alanya'nın turizm kenti dedikleri saptanmıştır. Kullanıcıların 286'sı deniz, kum güneş; 255'i iskele, 231'i Atatürk anıtı dedikleri saptanmıştır. Alanya kentini turizm kenti olarak tanımlamalarına rağmen, kent kimliği denildiğinde 203 kullanıcı turizm cevabını vermiştir.

Kullanıcıların \%39,5'i İskele-Rıhtım bölgesinde bulunan belediye hizmet binasının yerinde durmasına katılmadıkları görülmektedir. Katılmayan kullanıcıların 84'ü (\%21) kadın ve 74'ü $(\% 18,5)$ erkek olduğu tespit edilmiştir. Kullanıcıların \%40,8'i (163) bölgede bulunan Atatürk anıtının ve \%38,8'i (155) hükümet konağının yerinde durması gerektiğini düşündükleri saptanmıştır. Atatürk anıtının durması gerektiğini düşünen kullanıcıların \%15'i (60) ve hükümet konağının yerinde durmasını düşünen kullanıcıların \%10,5'i (42) 18-30 yaş aralığındadır. Kullanıcıların \%37,5'i (150) bölgedeki eğlence mekânlarının kesinlikle yerinde durması gerektiğini, yalnızca \%1'i (4) bölgede görsel kirlilik yarattığını ve kesinlikle durmaması gerektiğini söyledikleri görülmektedir. Kullanıcılara, Alanya kentinin kent meydanı görevini üstlenen Atatürk anıtının yeterli olup olmadığı sorulmuştur. Kullanıcıların \%47,5'ine göre kent meydanı için kesinlikle yetersiz kaldığı görülmektedir. Kesinlikle yetersiz kaldığını düşünen kullanıcıların \%27,25’i (109), Alanya kentinde 6-10 yıl arasında yaşadıkları görülmektedir. Kullanıcıların Atatürk anıtı dışında veya bu bölgede daha büyük ve kent bütününe hizmet eden bir kent meydanına intiyaç olup olmadığı sorulmuştur. Kullanıcıların \%48,3'ü (193) kesinlikle kent bütününe hizmet eden bir meydanın gerekli olduğunu düşündükleri saptanmıştır. Kullanıcılara bölgede şehrin güzelliklerini ve bölgede şehrin merkezinde hissedip, hissetmedikleri sorulmuştur. Kullanıcıların \%43,5'i (174) bölgede şehrin güzelliklerini hissettiklerini, $\% 31,8$ 'i kentin merkezinde hissettiklerini ve \%31,5'i ise bölgede şehrin merkezinde hissetme konusunda kararsız kaldıkları görülmektedir. İskele-Rıhtım bölgesinde Alanya kent kültürüne ait izler taşıyıp taşımadığı sorulmuş ve kullanıcıların \%37,8'i kesinlikle kültürel iz taşıdığı düşündükleri görülmüştür. Kullanıcılara bölgenin, Alanya kent bütünüyle, tarihiyle bağlantı kurup kurmadıkları ve kent kimliğini bölge üzerinde etkilerini hissedip hissetmedikleri sorulmuştur. Kullanıcıların \%27,5'i uyumlu olduğunu, \%29,3'u kültürel iz taşıdığını ve kent kimliğini bölge üzerinde hissettiği saptanmıştır. Son olarak kullanıcılara bölgede kendilerini güvende hissedip hissetmedikleri sorulmuş ve \%41,5'i güvende hissettiklerini yalnızca toplam \% 7,8'i güvende hissetmedikleri tespit edilmiştir.

Kullanıcıların yaşam sürelerine göre kent bütününde kent meydanının gerekli olup olmadığı incelenmiştir. Bu durumda; kullanıcıların yalnızca $\% 0,3$ 'ü (1) Alanya kentinde 0-5 yıl aralığında yaşıyor olup, kesinlikle kent bütününde kent meydanının gerekli olmadığı düşünmektedir. Kullanıcıların \%1'i (4) ise kent meydanına gerekli olmadığını düşünmektedir. En fazla 6-10 yıl arasında yaşayan kullanıcıların \%47,7'si kent bütünü için kent meydanının gerekli olduğuna kesinlikle katılmakla beraber, bu yıllar arasında yaşayan kullanıcıların \%37,6'sının da gerekli gördüğü saptanmıştır. Kararsız kullanıcıları ise toplam kullanıcıların $\% 14,75$ 'ini oluşturmakla beraber, 6-10 yıl ve 20 yılın üzerinde yaşayan kullanıcıların, kararsızların \%54,23'ünü oluşturduğu saptanmıştır.

Kullanıcıların yaşam sürelerine göre İskele-Rıhtım bölgesinde kendilerini şehrin merkezinde hissedip hissetmedikleri incelenmiştir. Buna göre; 400 kullanıcının \% 31,8 'i şehrin merkezinde hissettiklerine katıldıkları fakat \%31,5'ininde kararsız kaldığı görülmektedir. En fazla 16-20 yıl arasında Alanya kentinde yaşayan kullanıcıların \%10,5'i (42) kendini şehir merkezinde hissettiği, kullanıcıların \%9,25'inin (37) 6-10 yıl aralığında yaşayıp, kararsız kaldıkları saptanmıştır. 0-5 yıl aralığında yaşayan kullanıcıların \%64,10'u şehrin merkezinde hissetmemekle beraber kararsız kaldıkları, tüm yaşam sürelerine baktığımızda ise bütün kullanıcıların \%2,25'inin bu bölgede kesinlikle şehrin merkezinde hissetmedikleri görülmüştür. Kullanıcıların 0-5 yıl arası yaşayan ve 20 yıl üzeri yaşayan kullanıcıların, İskeleRıhtım bölgesinde iken kendilerini şehir merkezinde hissettiklerini en az hisseden kullanıcılardan oluştuğu saptanmıştır. Kullanıcıların \%46,25'i (185) kendilerini şehrin merkezinde hissettiklerini fakat bu kullanıcıların $\% 34,05$ 'i bölgede şehrin merkezinde hissetmedikleri saptanmıştır.

\section{SONUÇ}

Insanların bir araya gelme ve bir arada yaşama isteğinin ürünü olan kentler, kırsal yerleşmelerde yaşam şekillerinin değişimi ve başkalaşımın mekâna yansıdığı yerleşim biçimleridir. Kentlerin oluşumunda farklı değişkenler etkili olmuş; kentlerle birlikte kentsel mekânlar ortaya çıkmış ve gelişmiştir. Söz konusu değişkenler farklı işlevlerde mekânların oluşmasına ve farklı işlevlerdeki mekânlar da kentlerin farklı kimliklere sahip olmasına neden olmuştur. Kimlik sahibi kentlerdeki kentsel mekânların başında ilk ortak mekân olan kent meydanları ortaya çıkmış, kent kimliğinin değişimiyle beraber değişmiş ve gelişmiştir.

Kentsel mekânların ortaya çıkmasıyla birlikte, kentlerin konumları, kuruldukları coğrafya ve topografik durumuyla birlikte, toplumların yaşam biçimleri kentsel mekânları geliştirmiştir. Kentsel mekânların gelişimi ve değişimi de kentlerin kendine özgü betimlemelerin yapılmasına olanak sağlamıştır. Böylece bir kentin kimliği, kenti tanımlayan, farklı özellikleri ile birbirinden ayıran ve kentin kimliğini oluşturan bileşenlerden biri olan kent 
meydanları, kentin kimliğini yansıtan kentsel mekânları olarak karşımıza çıkmaktadır.

Kent meydanları, kent yaşamının önemli parçalarından biri olup; değişen ve gelişen sosyo-kültürel ve sosyoekonomik yapının şekillenmesinde etkili olmuştur. Kent meydanları, kentin kamusal mekânları olması nedeniyle, kent kimliğinin toplumsal yönünü oluşturmaktadır. Kısacası kent meydanları, toplumun kültür, medeniyet, ekonomik durumunun göstergesi olup, tarihsel izleri taşıyan yapılarla da şekillenmesiyle kentin kimliğini yansıtmaktadır.

Kent meydanlarının biçimlenmesinde, toplumsal faktörler belirleyici olurken, oluşumunda ise mimari ve sanatsal öğeler, yapı cepheleri, yollar, sokaklar, bitki örtüsü gibi öğeler önemli role sahiptir. Bu öğelerle birlikte kent meydanları, kentin tarihini ve ortak kültürünü yansıtan mekânlardır. Kısacası, kent kimliğini oluşturan toplumsal ve çevresel (doğal ve yapay) kimlik bileşenleri, kent meydanlarını etkileyen öğelerdir.

Genel olarak; bu çalışma kapsamında Alanya kent merkezinde seçilen İskele-Rıhtım bölgesi, kentte yaşayan ve ziyarete gelen insanların bir araya geldiği kentsel mekânlardan oluşup, Alanya kent kimliği bileşenlerinin gözlemlendiği ve bu kimliğin yansıdığı bölge konumundadır. Bu bölge ve çevresinde konumlanan tarihi ve kültürel yapılar, anıtlar, kültürel, sosyal, ekonomik ve siyasal farklı aktivitelerin yapıldığı ufak meydanlar, farklı işlevlere sahip modern yapılar, deniz, önemli karayolları ile çevrelenmesiyle birlikte insanların bir araya geldiği, kentin odak ve düğüm noktası olarak Alanya kent kimliğinin yansıdığı mekândır. İskele-Rıhtım bölgesini bir bütün olarak ele aldığımızda; geçmişten günümüze tarihi izler taşıyan yapılar, bu bölge ile birlikte bir uyum içerisinde, günümüzde hala etkisini sürdürmekte olup, tarihsel süreçte kent kimliğini yansıtmaktadır.

İskele-Rıhtım bölgesi sınırları içerisinde bulunan; Atatürk anıtının bulunduğu meydan, rıhtım-şelale meydanı, belediye hizmet binasının arkasında bulunan alan ve Kızılkule çevresinde bulunan ufak alan kentte etkinlik ve aktivitelerin yapıldığı açık alanlardır. Ancak, bu alanlardan Atatürk anıtının bulunduğu meydan ve rıhtımşelale meydanı her ne kadar meydan olarak adlandırılsa da, yalnızca ufak kutlamalar ve etkinliklerin olduğu kentsel mekânlardır. Bu durumda, Atatürk anıtının bulunduğu meydan, araç trafiğinin yoğun olduğu bölgede konumlanmakta olup, etkinliklerin yapılması için yetersiz kalmaktadır. Geçmişten günümüze bu bölge kent meydanı görevi üstlenmekle birlikte, hızlı nüfus artışı ve kentsel gelişmelerin soncunda, kent kimliğini yansıtan fakat yetersiz kalan kentsel mekândır. Kent kimliği doğrudan yansıttığını ve etkilediğini söylemek mümkündür.
$\mathrm{Bu}$ meydanın bulunan, güneyinde belediye hizmet binasının arka tarafında deniz ile arada kalan açık alan, bu meydanların yetersiz kalmasından dolayı etkinliklerin ve aktivitelerin yapıldığı alandır. Genel olarak bu meydanlar ve dış mekânlar, toplumsal ilişkilerin güçlenmesini ve kimlikli mekânların oluşmasını sağlamaktadır. Söz konusu bu meydanlar ve alanlar, İskeleRıhtım bölgesi üzerinde, yaya sirkülasyonunun da sağlandığı bir aks üzerinde birbiriyle ilişkili konumdadırlar.

Kıyı ovası ve çevresine yerleşmiş bir kent olan Alanya, kent bütününde uzun bir kıyı bandına sahiptir. İskeleRıhtım bölgesi kıyı boyunca, bu kentsel mekânlarla birlikte revize edilerek ve daha büyük mekânlar oluşturularak, kentin tarihiyle bağlantı kurulmasına, yaya sirkülasyonu güçlendirilerek kıyı üzerinde bir bütün şeklinde benzer mekânlar oluşturularak kullanıcıların rahat nefes alabileceği açık alanlar durumuna gelecektir.

Kentlerin sosyo-kültürel ve sosyo-ekonomik kimliklerini en iyi şekilde yansıtan kent meydanlarıdır. Kentin kimliğinin olumlu ya da olumsuz yönde gelişmesini etkilemekte olup, bu bağlamda Alanya kenti İskele-Rıhtım bölgesi göz önünde bulundurulduğunda; bölge bir bütün olarak kullanıcılar tarafından kent meydanı olarak düşünülmekte ve kentlileri bir araya getiren, etkileşimlerini sağlayan ve kent kimliğine olumlu yönde etkileyen bölge konumundadır. Alanya kentinin tarihi ve modern dokularından izler taşıyan bu bölge, kimlik bileşenlerinin sergilendiği ve bu kimliğinde mekâna yansıyarak kenti ifade ettiği görülmektedir.

Alanya kenti için geçmişten günümüze baktığımızda; kent meydanları tarihsel süreçte sürekli değişim içerisinde olup, değişen kültürel ve ekonomik faaliyetlerle değişime uğramıştır. 1970'lere kadar önem arzeden Kuyularönü Meydanı, zamanla önemini yitirmiş ve trafik kavşağı konumuna gelmiştir. 1980'lerden sonra günümüzde Atatürk anıtının bulunduğu meydan ise, Atatürk anıtından önce, meydanda bir çeşme ve ulu bir çınar kentin kimliğini yansıtan imaj öğesi olmuştur. Şuan da meydanın güneyinde kalan belediye hizmet binasının taşınması için 2017 yılında çalışmalara başlanmıştır. Böylelikle belediye hizmet binasının taşınması ile meydan ile deniz arasında kalacak alan eksikliği ve gerekliliği düşünülen kent meydanı için uygun bir açık alan olduğu söylenilebilir. Yapılan anket çalışmasında da kullanıcıların \%84'ü kent bütününe hizmet eden bir kent meydanına ihtiyaç olduğunu söylemiş, yapılan tüm aktivite ve etkinliklere baktığımızda, İskele-Rıhtım bölgesinde gerçekleştirildikleri görülmüş ve bu alanın kent meydanı için en uygun alan olduğunu söylemek mümkündür. 
Kent kimliğinin kent meydanlarına yansıması Alanya İskele-Rıhtım bölgesini ele alındığında; kentin fiziksel ve toplumsal karakterleri kent kimliğini oluşturmuştur. Oluşan bu kent kimliğinin Alanya kentinde en iyi yansıdığı bölgenin İskele-Rıhtım bölgesi olduğunu söylemek mümkündür. Gelişen ve değişen kentlerde, teknoloji ve nüfusun artması ile birlikte plansız ve kimliksiz kentler oluşmuştur. Kentleri oluşturan toplumsal ve çevresel kimlik bileşenleri, kent bütününde plan çalışmaları kapsamına alındığında ve bir bütün olarak düşünüldüğünde kimlikli kentlerin oluşmasına ve bu kimliğin yansıdığı kent meydanlarına yansımasına etken olacaktır.

\section{KAYNAKLAR}

Altınçekiç Çınar, H.S. (2000). İstanbul Metropolü'nde Meydanların Rekreasyonel İşlev Yönünden Önemi Üzerine Araştırmalar. İstanbul Üniversitesi, Fen Bilimleri Enstitüsü, Peyzaj Mimarlığı Anabilim Dalı, Doktora Tezi, 255s, İstanbul.

Altınçekiç Çınar, H., S., Ergin, B., Tanfer, M. (2014). Tarihsel Süreç İçinde Kent Kimliğinin Mekansal Kalite Değerlendirmesi Üzerine Bir Araştırma (Taksim Meydanı). Artvin Çoruh Üniversitesi Orman Fakültesi Dergisi, 15(2): 132148.

Alanya Belediyesi (2018). Plan ve Proje Müdürlüğü.

Antalya Büyükşehir Belediyesi (2018). Kent Bilgi Sistemi.

Aykurt, A. S. (2010). Planlama Ve Uygulama Süreçlerinde Kent Meydanları: Antalya Cumhuriyet Ve Konyaaltı Kent Meydanlarında Karşılaştırmalı Bir Araştırma. Akdeniz Üniversitesi, Fen Bilimleri Enstitüsü, Peyzaj Mimarlığı Anabilim Dalı, Yüksek Lisans Tezi, 130s, Antalya.

Bayramoğlu, N. (2010). Kullanıcı Algısı Bağlamında Kentsel Kimlik: Barbaros Bulvarı Büyükdere Kentsel Aksı. İstanbul Teknik Üniversitesi, Fen Bilimleri Enstitüsü, Disiplinlerarası Anabilim Dalı, Yüksek Lisans Tezi, 147s, İstanbul.

Correa, C. (1983). Quest for Identity, Architecture and Identity, Exploring Architecture In Islamic Culture Seminar.
Universiti Teknologi Malaysia any Ministry of Culture, 2527 July, 10-13.

Erdönmez, M. E., Akı, A. (2005). Açık Kamusal Kent Mekanlarının Toplum İlişkilerindeki Etkileri. Megaron YTÜ Mimarlık Fakültesi e- Dergisi, 1(1), 67-87.

Kalender Ölmez, S., Demiroğlu, D. (2011). Tarihi Süreç İçerisinde Sivas Kent Meydanı'nın İrdelenmesi. İnönü Üniversitesi Sanat ve Tasarım Dergisi, 1(3): 355-365.

Marcus, C., Francis, C. (1990). People Places: Desing Guidelines forr Urban Open Space. New York: Van Nostrand Reinhold.

Mesutoğlu, M. (2001). Kentsel Mekan Olarak Meydan Ve Morfolojik Özellikleri. Yıldız Teknik Üniversitesi, Fen Bilimleri Enstitüsü, Şehir ve Bölge Planlama Anabilim Dalı, Yüksek Lisans Tezi, 78s, İstanbul.

Moughtin, C. (2003). Urban Design Street and Square. Architectural Press Third Edition, 300s, Oxford.

Özdeş, G. (1985). Şehircilik. İstanbul Teknik Üniversitesi, Mimarlık Fakültesi, İstanbul.

Özkan, M.B. Küçükerbas, E.V., Kaplan, A., Hepcan, S., Malkoç Yigit, E., Sönmez, H. (1994). Muğla Kenti Kamusal Dış Mekânları Bağlamında Master Plan Çalışması. Ege Üniversitesi, Ziraat Fakültesi, Peyzaj Mimarlığı Bölümü, Ege Üniversitesi Basımevi, İzmir.

Schulz, C. (1971). Existence, Space and Architecture. Studio Vista, New York.

Şahin, B.E. (2006). Meydanların Kentsel Yaşama Katkısı Üzerine Bir İnceleme: Bursa Örneği. Uludağ Üniversitesi, Fen Bilimleri Enstitüsü, Mimarlık Anabilim Dalı, Yüksek Lisans Tezi, 275s, Bursa.

Taşçı, H. (2012). Kent Meydanı ile Kent Kimliği İlişki 'Üsküdar Meydan Örneği'. Marmara Üniversitesi, Sosyal Bilimler Enstitüsü, Kamu Yönetimi Anabilim Dalı, Mahalli İdareler ve Yerinden Yönetim Bilim Dalı, Doktora Tezi, 383s, İstanbul.

Topçu Deniz, K. (2011). Kent Kimliği Üzerine Bir Araştırma: Konya Örneği. Uluslararası İnsan Bilimleri Dergisi, 8 (2): 1048-1072.

Zucker, P. (1959). Town and Square. Columbia University Press, New York. 